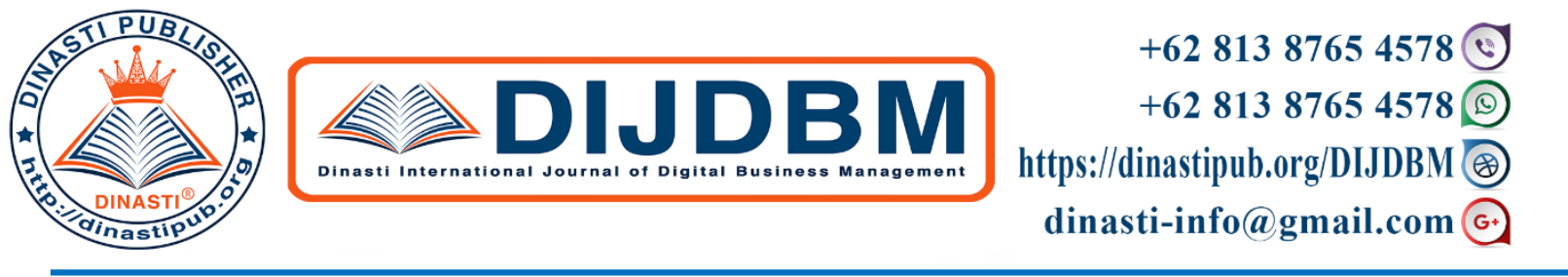

\title{
THE IMPACT OF KINDERGARTEN HEAD'S MANAGERIAL COMPETENCY ON IMPROVING PRESCHOOL EDUCATIONAL QUALITY
}

\section{Yessy Widiastuty' ${ }^{1}$, Muji Gunarto ${ }^{2)}$}

1) Management Magister Bina Darma University, Palembang, Indonesia

${ }^{2)}$ Economic and Business Faculty, Bina Darma University, Palembang, Indonesia

\begin{tabular}{|c|c|}
\hline $\begin{array}{l}\text { ARTICLE INFORMATION } \\
\text { Received: } 30 \text { January } 2020 \\
\text { Revised: } 5 \text { February } 2020 \\
\text { Issued: } 20 \text { February } 2020 \\
\text { (filled in by Editor) } \\
\text { Corresponding author: } \\
\text { Muji Gunarto } \\
\text { E-mail: } \\
\text { mgunarto@ binadarma.ac.id }\end{array}$ & $\begin{array}{l}\text { Abstract: The purpose of this study is to examine the } \\
\text { impact of managerial competency on improving } \\
\text { education quality in preschool education. When the } \\
\text { kindergarten head has managerial competency, she is } \\
\text { able to manage, regulate and move the educational } \\
\text { institution to the maximum in achieving the } \\
\text { institution's targets and ideals stated in the vision and } \\
\text { mission of the institution with high and measurable } \\
\text { quality of education. This research survey was } \\
\text { conducted in one sub-district in Palembang city, } \\
\text { Indonesia. The samples were } 131 \text { kindergarten heads, } \\
\text { teachers and administrative staff from } 12 \text { kindergartens } \\
\text { in Ilir Barat } 1 \text { district Palembang city. The sampling } \\
\text { technique used is random and the data analysis used is } \\
\text { structural equation modelling (SEM) analysis. The } \\
\text { results show that the managerial competency of the } \\
\text { kindergarten head has a positive and significant impact } \\
\text { on improving the preschool educational quality, as } \\
\text { well as improving the image of the institution in the } \\
\text { community. } \\
\text { Keywords: competency, managerial, kindergarten, } \\
\text { educational quality, preschool education }\end{array}$ \\
\hline
\end{tabular}

\section{INTRODUCTION}

All countries in the world have their own systems and ways of organizing education intended for their citizens, for example: in Japan, basic education is held based on patterns of habit for character formation (Peter, 2007). In Finland, school means play, by playing children learn some aspects of education they need. (Nevanen, Saila1; Juvonen, Antti2; Ruismäki, 2014). Likewise, Indonesia has its distinctive in organizing education, namely by continuing and in several ways (Raharjo, 2012). The government also legalizes it in regulations to ensure that all people find their rights to good education and in accordance with their age formally, informally and nonformally. (Usman, 2014) 
In the Law of the Republic of Indonesia Number 20 Year 2003 Chapter General Provisions Article 1 states that formal education is a structured and tiered education pathway from basic education, secondary education, and higher education. Before entering primary education, children need to prepare themselves to start their formal education by participating in firing activities at an early age education. Early childhood education is a coaching effort given to children from birth until the age of six years by providing educational stimuli to help physical and spiritual growth and development so that children find themselves ready to get further education, namely : learning in TPA and or SPS at birth - 2 years; at TPA, KB and / or SPS at the age of 2-4 years; and in KB, TK / RA / BA, TPA, and / or SPS aged 4-6 years.

According to the Ministry of Education and Culture reference data as of November 2019, in Palembang there are 446 TK / RA, 298 KB, 4 TPA and 62 SPS, so the total number of early childhood schools in Palembang that have been registered is 810 scattered in 18 districts. The number will increase if it is added again with preschool institutions which are in the registration process and those that have not yet registered, of which the number is certainly not small. From these data it can be concluded that the growth of early education in Palembang is so rapid even though early education does not include education that must be followed.

In Ilir Barat 1 sub-district, there are 74 registered early childhood education consisting of 45 TK / RA. 24 KB, 0 TPA and 5 SPS. The distance one institution to another is $<500 \mathrm{~m}$ $1 \mathrm{~km}$. And of the 74 early childhood education, only 1 kindergarten is a state kindergarten, the rest is managed privately and independently, which means that the kindergarten regulates everything itself including making policies regarding financing. This is important because at this time commercialization is happening in the institution of early childhood education with high costs being collected both the registration fee, building fees, academic fees / year and monthly fee. This is triggered by the high need for early childhood education although it is not compulsory but seems to be an unwritten requirement to register elementary school which makes parents competing to send their children to school as early as possible. Even now, early childhood education seems to be the backbone for elementary schools with basic academic abilities such as counting, reading and writing abilities where children who are going to primary school are required to be able to read, write and count. And it becomes a burden for early education to achieve it. Therefore good management of this early education is needed so that it is able to achieve what the basic education demands. In other words, the quality of early childhood education is very important in determining the success of students in continuing basic education. And the principal as a person who is very responsible and plays a role in the management and regulation of early childhood education institutions in improving the quality of early childhood education.

The principal is the person who decides how education institution is run because he has the authority and role to regulate, manage and direct all components of education in the institution towards what is aspired (Fitrah, 2017). The headmaster of early childhood education in Ilir Barat 1 sub-district is almost entirely held by a woman and with a background of not an early childhood education graduate. Surely this has become a challenge for every school principal in carrying out her duties, roles and functions as a school principal. Moreover, they must be able to reach the principal competency standards set by the 
government as stipulated by the Republic of Indonesia Ministry of Education. 13 of 2007. Principal competencies are personality competency, managerial competency, entrepreneurial competency, supervision competency and social competency. (Amanah, 2018; Resawati \& Larashati, 2016)

Research on improving the quality of education has been carried out by early childhood education professional teachers and the application of school-based management in primary and secondary schools cannot be used to measure the ability of school principals in the work and move their institutions that lead to improving the quality of early childhood education, therefore this research needs to be done to prove the existence of school principals' managerial competence towards improving the quality of early education in Ilir Barat I district of Palembang.

\section{LITERATURE REVIEW}

\section{Education Quality}

Quality is the condition of an item or service that is appropriate and exceeds customer expectations so that he finds satisfaction with the goods or services. (Engkoswara \& Komariah, 2015; Koswara \& Triatna, 2013). Quality education is the fulfillment of all requirements and customer satisfaction for the education provided, through input that is processed so as to produce outputs and even outcomes (Engkoswara \& Komariah, 2015). The conditions set for the quality of education for early childhood education are achieved by children in all aspects of growth and development that include physical-motoric aspects, religious and moral values, cognitive, social-emotional, arts, and language all of which are summarized in the implementation of teaching and learning processes organized by an early age education institution. To achieve the above requirements, good management at an early age institution is needed, namely by applying Total Quality Management. Sallis (1993: 13) defines: "TQM or MMT is a philosophy and method used to help an educational institution to deal with change and create an agenda / activity related to new demands of customers which are insistently urgent, and the concept of TQM or MMT is is everyone who is in one institution regardless of their position, they are leaders and managers in their respective places (Sutarto, 2013).

In addition, it takes the supporting parts that become a prerequisite for having quality, namely "quality-oriented leadership, education and training (training), support structures, communication, rewards and recognition, measurement."(Hermawan \& Trianna, 2013). 3 factors to improve the quality of education, namely: a) fulfillment of the quality of human resources, costs, learning facilities as a source of education, b) the quality of the learning process that motivates students to learn effectively, and c) the quality of output in the form of knowledge, attitudes, skills and values score. (Engkoswara \& Komariah, 2015)

\section{Managerial Competency}

Competency is defined as the capabilities and abilities that exist in a person who served in carrying out their roles and duties for the responsibilities they carry so that they can be carried out properly. (Adi, 2016). In Permendiknas No. 13 of 2007 there are 5 Principal Competencies, namely personal, managerial, entrepreneurial, supervisory and social 
competencies. And managerial competence according to Permendiknas No. 13 of 2007 is "the ability or expertise of principals in planning, managing, leading, developing school resources and monitoring, evaluating and reporting the implementation of school activities programs with appropriate procedures". (Adi, 2016)

Managerial competence is very important to be owned by the principal of an early childhood education institution because it will add more value to parents in determining a school of choice for their child. With a good early childhood education institution managed, it will make parents not feel afraid and anxious to let their children do academic activities at the school given that their children are still at an early age who still need guidance and assistance when learning. Moreover, early childhood learning is not just learning to fold origami paper but learning their daily lives, such as: going to the toilet, eating and drinking according to manners, playing with friends, etc., which in its implementation must be monitored and accompanied by teachers to anticipate accidents in study. In addition, all matters and coordination of the teaching and learning process of young children is the direct coordination and communication by the school management to parents not to the child. Principals with good managerial competency then he is able to manage all school components to be able to carry out their respective duties properly so as to foster a sense of parental trust in the school and this will lead to an increase in the credibility of educational institutions in the eyes of surrounding communities and increasingly organized programs education is organized with a team solidarity that will lead to an increase in the quality of education in the educational institution.

This managerial competency will make it easier for principals to carry out their tasks and functions in accordance with the basic concepts of educational leadership, there are five functions of educational leaders, namely: 1) seeking the establishment of a fraternal atmosphere, cooperation without fear and limitations, 2) helping the team to organize themselves by participating as well as in stimulating, determining and explaining objectives, 3) helping the team determine work procedures, by helping the team in analyzing the situation to later determine what are the most practical and effective ways, 4) take responsibility in making decisions together with the Team leader providing opportunities for the team to learn from experience. The leader is responsible for the team's training to know and understand the process and content of the work carried out and is ready to evaluate the results honestly and objectively, 5) is responsible for efforts to develop and defend the organization's existence. (Rosmiati \& Kurniady, 2013)

That way, the principal will be able to bring the educational institution he leads to achieve the goals and ideals that have been declared.

\section{RESEARCH METHODS}

This type of research used in this study is a causal research method with an explanatory research design. "The method is based on positivism philosophy, and is used to examine a particular population or sample, collecting data using research instruments, quantitative / statistical data analysis, with the aim of testing hypotheses that have been established using two variables that have a causal relationship." (Sugiyono, 2014). In this study, we will look at the effect of the principal's managerial competency variable as an 
independent (exogenous) variable on improving the quality of early childhood education as an endogenous variable. This research was conducted in 12 kindergartens located in the district of Ilir Barat I Palembang. This research was conducted for 3 months starting on September 1 December 312019.

Population is a collection of objects or research subjects that have the number and characteristics determined by researchers to study and draw conclusions (Sugiyono, 2014). The population of this study is the principal, teachers and parents of students from 74 preschool institutions located in Ilir Barat District I. The sample is part of the number and characteristics possessed by the population (Sugiyono, 2014). The sample in this study were principals, teachers and parents of students from 12 kindergartens in Ilir Barat District I. The sampling technique used was simple random sampling or assuming that the population had homogeneous characteristics. Random sampling is expected to all populations have the same opportunity to be taken as a sample. Researchers found 180 respondents in 12 kindergartens in Ilir Barat I district of Palembang with 150 respondents returning the questionnaire and after checking only 131 questionnaires were filled out completely and completely.

The method of data collection is done by using questionnaires and observations. Primary data collection is carried out using a questionnaire containing statements that have been designed in such a way regarding the managerial competence of school principals and the quality of early childhood education in accordance with a sample that has been determined with a scale of scores using a Likert Scale of 5 (five) points with a positive question form ( favorable). For statement categories with answers: Strongly Agree, rated $=5$, Agree, rated $=$ 4 , Less agree, rated $=3$, Disagree, rated $=2$, Strongly Disagree, rated $=1$

The process of data analysis to prove the influence between variables using the structural equation modelling (SEM) approach, which is a combination of factor analysis, regression analysis and path analysis (Gunarto, 2013).

\section{FINDINGS AND DISCUSSION}

\section{Descriptive Analysis}

characteristics of respondents in this study were the majority of women with 122 respondents or $93.13 \%$, aged between 31-35 years with a total of 47 respondents or $35.88 \%$, with an undergraduate level (S1) education of 71 respondents or $54.20 \%$, and with years of service over 10 years a number of 62 respondents or $47.33 \%$ of the total 131 responses participated in this study. While minority respondents are male with 9 people or $6.87 \%$ with age less than 25 years with 22 respondents or $16.79 \%$ with a Diploma level of 13 people or $9.92 \%$ and tenure with 5-10 years of work which is 28 people or $21.37 \%$ of the total 131 responses that participated in this study.

\begin{tabular}{|c|c|c|c|c|c|c|c|c|c|c|}
\hline \multirow[b]{3}{*}{ Item } & \multicolumn{10}{|c|}{ Scales } \\
\hline & \multicolumn{2}{|c|}{1} & \multicolumn{2}{|c|}{2} & \multicolumn{2}{|c|}{3} & \multicolumn{2}{|c|}{4} & \multicolumn{2}{|c|}{5} \\
\hline & $\begin{array}{c}\text { Total } \\
\text { Res } \\
\text { pondent }\end{array}$ & $\%$ & $\begin{array}{l}\text { Total } \\
\text { Res } \\
\text { Pondent }\end{array}$ & $\%$ & $\begin{array}{c}\text { Total } \\
\text { Res } \\
\text { pondent }\end{array}$ & $\%$ & $\begin{array}{c}\text { Total } \\
\text { Res } \\
\text { pondent }\end{array}$ & $\%$ & $\begin{array}{c}\text { Total } \\
\text { Res } \\
\text { pondent }\end{array}$ & $\%$ \\
\hline$X$ & 0 & 0 & 12 & 0,571 & 663 & 31,554 & 910 & 43,436 & 510 & 24,284 \\
\hline $\mathbf{Y}$ & 45 & 0,954 & 155 & 3,305 & 1317 & 28,478 & 1812 & 38,633 & 1376 & 29,093 \\
\hline
\end{tabular}

Tabel 1. The respondents' perceptions to variable X ( managerial competency) and variable Y ( Quality) 
From the above table, it is known that respondents' perceptions of variable $\mathrm{X}$ were 12 respondents or $0.571 \%$ who disagreed (2), 663 people or $31.554 \%$ stated neutral (3), 910 people or $43.436 \%$ agreed (4) and 510 people or $24.284 \%$ expressed strongly agree. There were no respondents who expressed disagreement with variable $\mathrm{X}$. While respondents' perceptions of variable $\mathrm{Y}$ were 45 respondents or $0.954 \%$ stated strongly disagree (1), 155 people or 3,305\% stated disagreed (2), 1317 people or $28,478 \%$ stated neutral (3), 1812 people or 38,633\% agreed (4) and 1376 people or 29,093\% strongly agreed (5). This means that the respondent shows a high perception of the variables $\mathrm{X}$ and $\mathrm{Y}$ where the respondent's answer is agree (4) and strongly agree (5) on the statements on both variables. they realize that managerial competence is an important thing and determines the good and bad implementation of the teaching and learning process, while in the quality of education needed indicators that will support the achievement of educational quality standards in accordance with those set.

\section{Statistical Analysis with Structural Equation Model}

The statistical analysis used in this study is the structural equation model (Structural Equation Models - SEM) with the help of the LISREL 8.70 for Windows program. This is done because the variables used are latent variables and the model formed also has a structural relationship. A survey of 131 respondents was conducted to see the effect of the principal's managerial competence on improving the quality of early childhood education. Data processing with SEM LISREL method in this study consists of a model compatibility test, variance test, structural equation, and overall model fit.

\section{Model Match Test (validity and reliability)}

Test the suitability of the measurement model against each measurement model, related to the relationship between latent variables and manifest variables (observable variables). Measurement test is carried out by determining the validity and reliability of indicators in a construct. Validity test aims to measure the level of consistency of manifest variables in measuring latent constructs.

\begin{tabular}{ccccc}
\hline variabel & $\boldsymbol{\lambda}$ & $\boldsymbol{\lambda} \mathbf{2}$ & $\mathbf{e}=\mathbf{1 - \boldsymbol { \lambda } ^ { \mathbf { 2 } }}$ & $\mathbf{K e t}$ \\
\hline $\mathbf{X 1}$ & 0,83 & 0,6889 & 0,3111 & valid \\
$\mathbf{X 2}$ & 0,91 & 0,8281 & 0,1719 & valid \\
$\mathbf{X 3}$ & 0,9 & 0,81 & 0,19 & valid \\
$\mathbf{X} 4$ & 0,9 & 0,81 & 0,19 & valid \\
$\mathbf{X 5}$ & 0,92 & 0,8464 & 0,1536 & valid \\
$\mathbf{X 6}$ & 0,91 & 0,8281 & 0,1719 & valid \\
$\mathbf{X} 7$ & 0,81 & 0,6561 & 0,3439 & valid \\
$\mathbf{X 8}$ & 0,84 & 0,7056 & 0,2944 & valid \\
$\mathbf{X 9}$ & 0,86 & 0,7396 & 0,2604 & valid \\
$\mathbf{X 1 0}$ & 0,87 & 0,7569 & 0,2431 & valid \\
$\mathbf{X 1 1}$ & 0,77 & 0,5929 & 0,4071 & valid \\
$\mathbf{X 1 2}$ & 0,79 & 0,6241 & 0,3759 & valid \\
\hline
\end{tabular}




\begin{tabular}{ccccc}
\hline variabel & $\boldsymbol{\lambda}$ & $\boldsymbol{\lambda 2}$ & $\mathbf{e}=\mathbf{1}-\boldsymbol{\lambda}^{\mathbf{2}}$ & Ket \\
\hline $\mathbf{X 1 3}$ & 0,71 & 0,5041 & 0,4959 & valid \\
$\mathbf{X 1 4}$ & 0,81 & 0,6561 & 0,3439 & valid \\
$\mathbf{X 1 5}$ & 0,85 & 0,7225 & 0,2775 & valid \\
$\mathbf{X 1 6}$ & 0,89 & 0,7921 & 0,2079 & valid \\
& 13,57 & 11,5615 & 4,4385 & valid \\
Construct & & & & \\
Realibility & & 0,9765 & & Reliabel \\
( CR ) & & & & \\
Average & & & & \\
Variance & & 0,7225 & & \\
Extract & & & & \\
( AVE ) & & & & \\
\hline
\end{tabular}

Tabel 2. validity and reliability of competency source : primer data analysed, 2019

Based on table 2 above the value of $C R \geq O, 7(0.9765)$ and the value of AVE $\geq 0.5$ (0.7225), so it can be concluded that the construct for the variable Competence is Reliable.

\begin{tabular}{ccccc}
\hline Variable & $\boldsymbol{\lambda}$ & $\square \square$ & $\mathbf{e}=\mathbf{1 - \lambda ^ { \mathbf { 2 } }}$ & Ket \\
\hline Y1 & 0,83 & 0,6889 & 0,3111 & Valid \\
Y2 & 0,94 & 0,8836 & 0,1164 & Valid \\
Y3 & 0,88 & 0,7744 & 0,2256 & Valid \\
Y4 & 0,92 & 0,8464 & 0,1536 & Valid \\
Y5 & 0,94 & 0,8836 & 0,1164 & Valid \\
Y6 & 0,91 & 0,8281 & 0,1719 & Valid \\
Y7 & 0,9 & 0,81 & 0,19 & Valid \\
Y8 & 0,92 & 0,8464 & 0,1536 & Valid \\
Y9 & 0,86 & 0,7396 & 0,2604 & Valid \\
Y10 & 0,91 & 0,8281 & 0,1719 & Valid \\
Y11 & 0,91 & 0,8281 & 0,1719 & Valid \\
Y12 & 0,89 & 0,7921 & 0,2079 & Valid \\
Y13 & 0,93 & 0,8649 & 0,1351 & Valid \\
Y14 & 0,9 & 0,81 & 0,19 & Valid \\
Y15 & 0,85 & 0,7225 & 0,2775 & Valid \\
Y16 & 0,89 & 0,7921 & 0,2079 & Valid \\
Y17 & 0,65 & 0,4225 & 0,5775 & Valid \\
Y18 & 0,87 & 0,7569 & 0,2431 & Valid \\
Y19 & 0,82 & 0,6724 & 0,3276 & Valid \\
Y20 & 0,9 & 0,81 & 0,19 & Valid \\
Y21 & 0,89 & 0,7921 & 0,2079 & Valid \\
Y22 & 0,91 & 0,8281 & 0,1719 & Valid \\
Y23 & 0,89 & 0,7921 & 0,2079 & Valid \\
\hline & & & &
\end{tabular}




\begin{tabular}{ccccc}
\hline Variable & $\boldsymbol{\lambda}$ & $\square \square$ & $\mathbf{e}=\mathbf{1 - \boldsymbol { \lambda } ^ { \mathbf { 2 } }}$ & Ket \\
\hline Y24 & 0,89 & 0,7921 & 0,2079 & Valid \\
Y25 & 0,93 & 0,8649 & 0,1351 & Valid \\
Y26 & 0,95 & 0,9025 & 0,0975 & Valid \\
Y27 & 0,92 & 0,8464 & 0,1536 & Valid \\
Y28 & 0,92 & 0,8464 & 0,1536 & Valid \\
Y29 & 0,83 & 0,6889 & 0,3111 & Valid \\
Y30 & 0,91 & 0,8281 & 0,1719 & Valid \\
Y31 & 0,87 & 0,7569 & 0,2431 & Valid \\
Y32 & 0,95 & 0,9025 & 0,0975 & Valid \\
Y33 & 0,91 & 0,8281 & 0,1719 & Valid \\
Y34 & 0,91 & 0,8281 & 0,1719 & Valid \\
Y35 & 0,83 & 0,6889 & 0,3111 & Valid \\
Y36 & 0,89 & 0,7921 & 0,2079 & Valid \\
& 32,02 & 28,5788 & 7,4212 & \\
Construct & & 0,9928 & & \\
Realibility & & & & \\
( CR ) & & & & Reliabel \\
Average & & 0,7938 & & \\
Variance & & & & \\
Extract & & & & \\
( AVE ) & & & & \\
\hline
\end{tabular}

Tabel 3 validity and reliability of quality source : primer data analysed, 2019

Based on the table above the value of $\mathrm{CR} \geq \mathrm{O}, 7$ (0.9928) and the value of $\mathrm{AVE} \leq 0.5$ (0.7938), so it can be concluded that the construct for the variable quality is reliable.

Full model construct competency - quality 


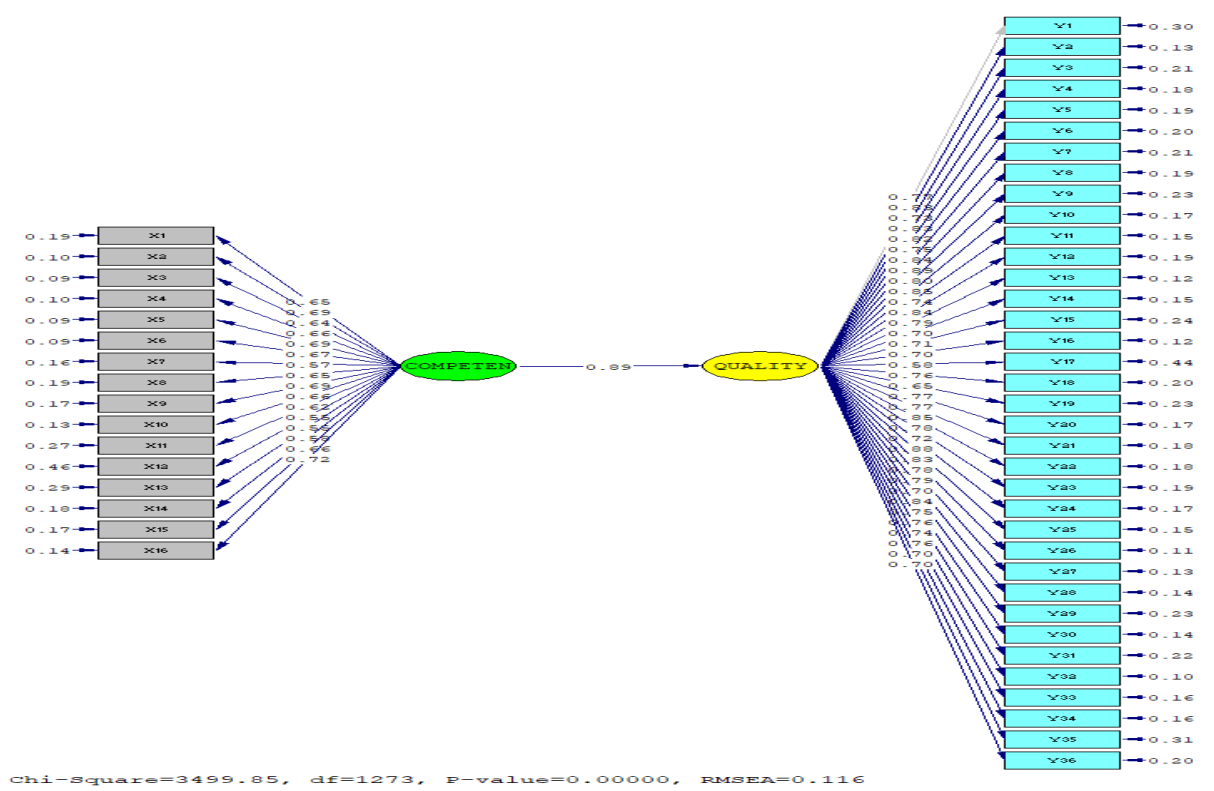

Picture

1.

Estimates full model construct of competency - quality, source : data analysed, 2019

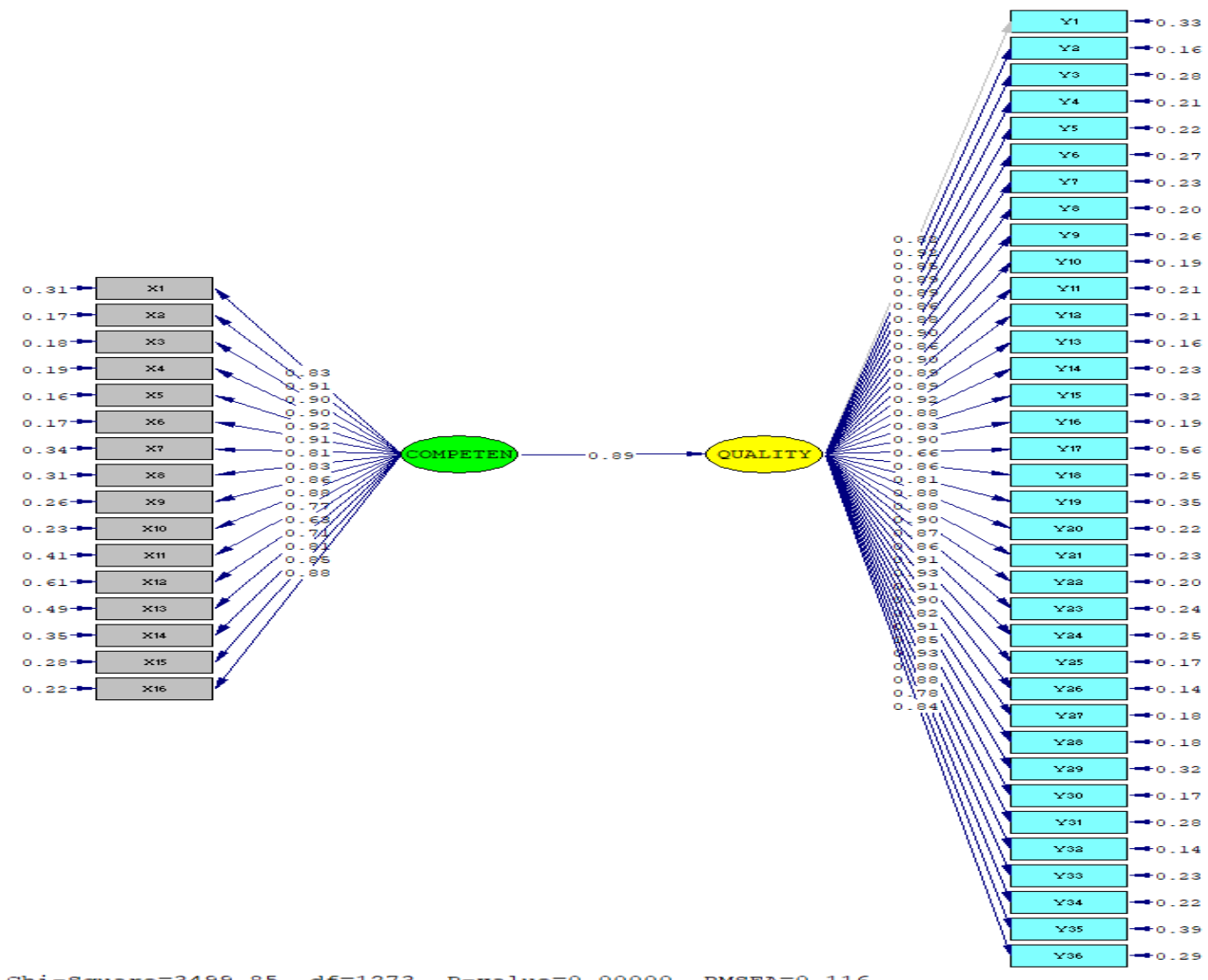

Picture 2. Standardized solution full model construct of competency - quality, source :data analysed,2019 


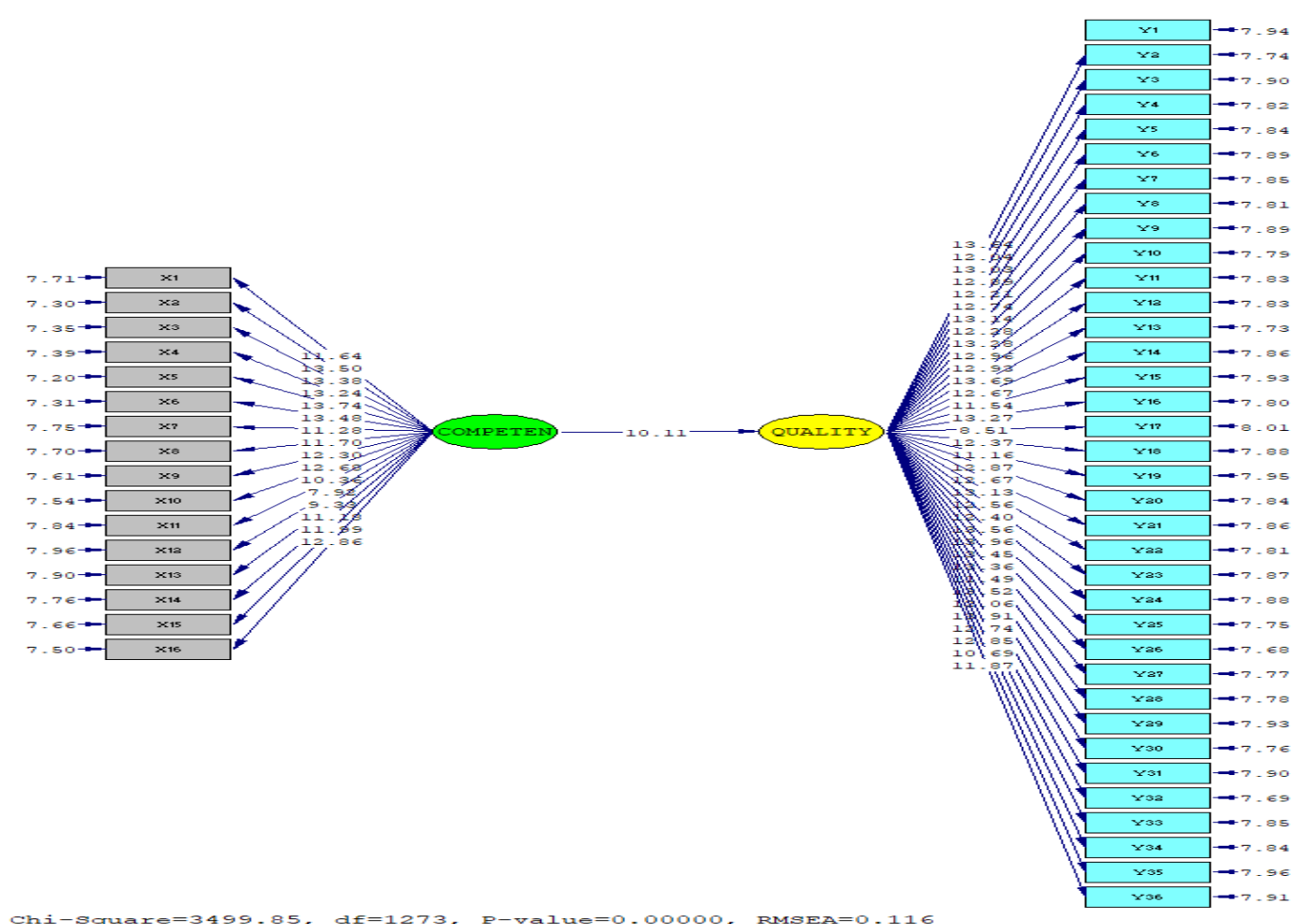

Picture 3. T - Value full model construct of competency - quality, source : data analysed, 2019

\begin{tabular}{clccc}
\hline \multicolumn{2}{c}{ GOODNESS-OF-FIT INDEX } & RANGE & VALUE \\
\cline { 1 - 2 } $\mathbf{N O}$ & Absolute/predictive fit indicates & & \\
$\mathbf{1}$ & chi square & Small & 3499.85 \\
$\mathbf{2}$ & Significance probability (P=Value) & & $\geq 0,05$ & 0,000 \\
$\mathbf{3}$ & X $^{2} / \mathrm{DF}$ & $<2$ atau 3 & 2,74 \\
$\mathbf{4}$ & RMR & $\leq 0,10$ & 0,039 \\
$\mathbf{5}$ & SRMR & $\leq 0,08$ & 0,045 \\
$\mathbf{6}$ & RMSEA & $\leq 0,08$ & 0.12 \\
$\mathbf{7}$ & GFI & $>0,90$ & 0,49 \\
$\mathbf{8}$ & AGFI & $>0,90$ & 0,45 \\
& Comparative fit indicates & & \\
$\mathbf{9}$ & NFI & $>0,90$ & 0,95 \\
$\mathbf{1 0}$ & IFI & $>0,90$ & 0,97 \\
$\mathbf{1 1}$ & CFI & $>0,90$ & 0,97 \\
& Parsimonious fit indices & & \\
$\mathbf{1 2}$ & PNFI & $>0,90$ & 0,91 \\
$\mathbf{1 3}$ & PGFI & $>0,90$ & 0,45 \\
$\mathbf{1 4}$ & AIC & small & 3789.85 \\
\hline
\end{tabular}

Tabel 4. Goodness of Fit, source : data analysed, 2019

In the table above, there are still some goodness of fit (GOF) statistical criteria that are not yet fit such as chi-square, p-value, RMSEA, PGFI, AGFI, and GFI. Small or insignificant chi-square values are difficult to fulfill especially in large, but that does not mean that the model is not suitable, so it is recommended to use other matching criteria. As stated earlier that a significant $\mathrm{p}$-value does not mean that the model is always not good, because the p- 
value is influenced by the large number of samples (Gunarto, 2013). Some goodness of fit (GOF) statistical criteria such as PNFI, CFI, IFI, NFI, SRMS, X2 / DF, and RMR are already fit, so that the final model of measuring Service Quality meets the criteria of a good measurement model (fit) and can be used as a manifest for the construct variable ful competency and quality models.

In picture 3 above it can be seen that Managerial Competency has a significant effect on Educational Quality with a t-value> 1.96, which is 10.11. From the above equation it can be seen that competence affects quality by $89 \%$. Thus it can be concluded that the principal's managerial competence has a positive and significant effect on the quality of early childhood education in Ilir Barat 1 sub-district.

\section{Discussion}

The results of this study indicate that the managerial competence of school principals has a positive and significant effect on the quality of early childhood education in Ilir Barat sub-district 1. This illustrates that the higher the managerial competency of a kindergarten head, the higher and better the quality of early childhood education in institutions he leads. Managerial competence is a very important competency possessed by a kindergarten head in carrying out their duties and roles as top leaders in an early age education institution. This result is in accordance with the leadership theory delivered that the kindergarten head really functions and has an important role in the progress and development of the school, whether or not the educational goals are achieved, whether or not the quality of the school is in the hands of the kindergarten head (Rosmiati \& Kurniady, 2013) . Therefore, a kindergarten head should have the ability and readiness to encourage, influence, accompany, invite, direct, move, and force people or many people if needed to accept that influence and then do what can help to achieve the specified goals. And that ability and readiness is called leadership and is called educational leadership because it is implemented and carried out in a school. To be able to carry out their duties and roles as head of kindergarten as explained above, the head of kindergarten must have managerial competence so that he knows what must be done in leading and moving all components of the school towards the targets and ideals of the institutions that have been stated in the vision and mission of the school. . Anyone can be the head of a kindergarten either appointed or appointed or makes himself head of the kindergarten, but the leadership will not make the institution of good quality if the leader does not have managerial skills in carrying out his duties and roles. And because of this managerial ability, a kindergarten head is able to carry out management functions, namely planning, organizing, motivating, innovating and controlling(Engkoswara \& Komariah, 2015) in his leadership. Therefore managerial competence is one of the skills or competencies that must be possessed by a kindergarten head as stipulated in Permendiknas No. 13 of 2007. And because this is a competency, every kindergarten head can learn and improve his leadership by increasing his managerial ability. Even more than that, with that managerial skill, he was able to make his institution have the quality of education in accordance with the standards set by the government and be able to improve the quality to be better and increase dynamically over time. 


\section{CONCLUSION AND SUGESTION}

\section{Conclusion}

Based on the results of research and discussion that has been done, the following conclusions are obtained:

1. Respondents' perceptions of each variable, namely managerial competence and quality are perceived to be high or very good. This shows that the 2 variables studied were highly perceived by respondents or in other words the components of early education institutions such as kindergarten heads, teachers and administrative staff have performed their duties and roles in accordance with those specified in the managerial competency items in order to improve quality early childhood education in the district of Ilir Barat 1 Palembang city.

2. Principal's managerial competence has a positive and significant effect on the quality of early childhood education in Ilir Barat sub-district 1 . This means that the managerial skills of a kindergarten head determine the quality of early childhood education in early childhood education institutions specifically in the district of Ilir Barat 1, Palembang.

\section{Suggestion}

To make an early education institution able to further improve the quality of its education, then there are some suggestions that need to be done include:

1. Each kindergarten head should have the managerial competence of the principal in order to facilitate and facilitate the implementation of his duties and roles as a kindergarten head in directing, mobilizing and maximizing efforts in achieving the targets and ideals that have been announced.

2. The need to increase managerial competency skills for the head of kindergartens in Ilir Barat 1 sub-district so that the quality of early childhood education in his institution becomes good and increases for the better over time.

\section{REFERENCE}

Adi. (2016). Implimentasi Kompetensi Manajemrial Kepala Sekolah Kecamatan Kuala Kampar Kabupaten Pelalawan Propinsi Riau. Jurnal Akuntabilitas Manajemen Pendidikan, 4(1).

Amanah, R. (2018). Kompetensi Kepala Sekolah dalam Meningkatkan Kinerja Guru di SD Muhammadiyah 07 Randudongkol Pemalang. Kompetensi Kepala Sekolah Dalam Meningkatkan Kinerja Guru Di SD Muhammadiyah 07 Randudongkol Pemalang.

Engkoswara, H., \& Komariah, A. (2015). Administrasi Pendidikan. Bandung: Alfabeta.

Fitrah, M. (2017). Peran Kepala Sekolah dalam Meningkatan Mutu Pendidikan. Jurnal Penjaminan Mutu, 3(1). https://doi.org/10.25078/jpm.v3i1.90

Gunarto, M. (2013). Membangun Model Persamaan Struktural (SEM) dengan Program Lisrel. Palembang: Tunas Gemilang Press.

Hermawan, D., \& Trianna, C. (2013). Organisasi Pendidikan. In Manajemen Pendidikan (pp. 
67-84). Bandung: Alfabeta.

Koswara, D., \& Triatna, C. (2013). Manajemen Peningkatan Putu pendidikan. In Manajemen Pendidikan (pp. 287-310). bandung: Alfabeta.

Nevanen, Saila1; Juvonen, Antti2; Ruismäki, H. (2014). Kindergarten and school as a learning environment for art. International Journal of Education Through Art, 10(1). https://doi.org/DOI: https://doi.org/10.1386/eta.10.1.7_1

Peter, C. (2007). Primary School in Japan Self, Individuality and Learning in Elementary Education (1st ed.). https://doi.org/https://doi.org/10.4324/9780203935811

Raharjo, S. B. (2012). Evaluasi Trend kualitas Pendidikan di Indonesia. Jurnal Penelitian Dan Evaluasi Pendidikan, 16(2), 511-532. https://doi.org/https://doi.org/10.21831/pep. v16i2.1129

Resawati, R., \& Larashati, I. (2016). Pengaruh Kepemimpinan Kepala Sekolah, Kompetensi Guru dan Kompensasi Kinerja Guru. Jurnal Ekonomi, Bisnis \& Entrepreneurship, 10(2), $132-148$.

Rosmiati, T., \& Kurniady, D. A. (2013). Kepemimpinan Pendidikan. In Manajemen Pendidikan (pp. 125-162). bandung: Alfabeta.

Sugiyono. (2014). Metode Penelitian Kuantitatif Kualitatif dan R\&D. Bandung.

Sutarto, H. (2013). Manajemen Mutu Terpadu (MMT-TQM). In UNY Press (Vol. 84). Retrieved from http://ir.obihiro.ac.jp/dspace/handle/10322/3933

Usman, A. S. (2014). Meningkatkan Mutu Pendidikan Melalui Penerapa Manajemen Berbasis Sekolah. Jurnal Ilmiah DIDAKTIKA, 15(1), 